\title{
Social Success of Future Primary School Teachers in the Process of Professional Training \\ Marfuga Absatova
}

Doctor of philological sciences, professor, Shakarim street 1, Abai Kazakh National Pedagogical University Almaty, Kazakhstan, 050009; absatovamar@mail.ru

\author{
Akkenzhe Ussenova \\ PhD student, Abai Kazakh National Pedagogical University, Shakarim atreet 13/63 \\ Almaty, Kazakhstan.050009; akkenzhe_08@mail.ru
}

\begin{abstract}
Alma Ordahanova
PhD student, Abai Kazakh National Pedagogical University, "Mamyr 3" Apartment 19, Almaty, Kazakhstan.050036; alma_ord@mail.ru

Adlet Kariyev

senior lecturer, Almaty University, Aksai 3/36, Almaty, Kazakhstan, 050031; adlet.kari@mail.ru

\section{Ainur Duisenbayeva}

senior lecturer, Almaty University, Musirepov atreet 1a, Almaty, Kazakhstan, 040708; aikoke81@mail.ru
\end{abstract}

\section{Doi:10.5901/mjss.2015.v6n6s4p476}

\section{Abstract}

The article shows the results of future primary school teachers' social success diagnosis; it also identifies criteria, indicators and methods of diagnosis development of future primary school teachers' social success and highlights the levels of future primary school teachers' social success. The research objective was to study the level of social success of future primary school teachers in pedagogical process of high school. Social success of future primary school teachers in the teaching process of the University is a holistic system, content and semantic unity of such components as social position, personal success, and social activity developed in socio-cultural activities to ensure the successful fulfillment, personal satisfaction and social recognition.

Keywords: social success, self-fulfillment, personal satisfaction, social recognition.

\section{Introduction}

In modern conditions of limited instability of social consciousness, students in the process of professional and personal identity are trying to distinguish and adopt the norms of their new adult life. One of the socially important personality characteristics that contribute to effective socialization of student youth is a social success. The condition of success contributes to the formation of such important human qualities like self-confidence, self-esteem, dignity.

Problems of success of a person is being developed in foreign psychology in studies of adaptation of personality for many years, highlighting success factors, motivation for success. The domestic science has works on the effectiveness of individual and group activities, achievement of objectives.

However, existing studies do not give the full answer to the question about development features of social success of future primary school teachers. In recent studies on the improvement of the educational process in universities, these issues are also not considered. Modern requirements to professional training of primary school teachers involve the development of new, more effective approaches for the development of social success of future teacher of primary school. With the development of social success of future primary school teachers, the basic guideline is the development 
of personal and professional qualities of the teacher.

The purpose of the research is the level of social success of future primary school teachers in the pedagogical process of high school.

These research methods were not chosen by chance. Research methods used in the experiment is sufficient to objectively determine the level of social success of future primary school teachers in the pedagogical process of high school.

In the pedagogical aspect the success is understood as a quality inherent in the personality, who has achieved success in the process of training and education. It may be the success of the student in learning, and the success of the teacher in training students, and the success of parents in the upbringing of children.

The success viewed as a particular orientation of the person with the characteristic motivation to achievement, values, communication skills, cognitive skills and the ability to control emotions. Based on the fact that social success in research is characterized as a certain state of a person associated with the satisfaction regarding its position in the social environment and its objective characteristics, we must apply to the study of socio-psychological factors of success.

The success is realized by man in the process of acquiring social experience, socio-cultural values of society and is achieved by the youth due to the efforts and diligence. Due to N. B. Krylova ((1995) the success is determined by five factors: a belief in their own potential, amount of effort, cooperation, complexity of the task, success in achieving the result. The readiness of the individual to solve difficult tasks in life is evident in the confidence necessary for social success. The more of success in the relevant field a person achieves, the more he is self-confident and respects himself. Successful person sets himself a target of opportunity, is able competently to achieve them: in a timely manner, with a minimum expenditure of energy, in harmony with the life and circumstances.

According to O. S. Gazman and I.S. Kon (1996) successful people are those who obtain the greatest results with the least emotional and energetic costs. Their prosperity is due to the ability to always carry out their plans on time, the ability to feel the situation, to apply the tools adequate to the task.

S. V. Kovalev (2002), interpreting the theory of hierarchy of human needs by A.Maslow, identified the following traits of a successful person: the full acceptance of reality and a comfortable attitude; self-acceptance and social environment; professional passion for favorite things; autonomy from the social environment and the opinions of others; ability to understand other people; the desire for novelty and openness to experience; a clear, but flexible representation of goals and means of its implementation; the immediacy and naturalness of behavior; sense of humor; self-development, self-actualization; the willingness to awareness of problems and difficulties, the true understanding of their capabilities.

Social success of such personality traits, integrating the result, allows to be fully integrated into the system of social ties and relations, contributing to the acquisition of socially desirable status on which a person builds relationships with other people and treats himself. Social success, being a prerequisite and a consequence of social interaction, indicates the ability of a man to realize himself in society as socially full of the subject, independently to set goals for themselves and reach them informed about development of self-esteem, confidence in their position in society.

Social success is closely connected with the protection of the individual, defined as "the subjective experience of individual to welfare of his own life, its success as a world-view, which gives confidence in the correctness of selected life goals, as a basis for the dignity and feelings of self-sufficiency, safe and self-realization" (Basova V.M. 2002)

Social success, being a prerequisite and a consequence of social interaction may be characterized as a stable state of the individual based on a positive "self-concept", which reflects its involvement in the system of social ties and relations as socially fledged subject that contribute to effective socialization and achievement of socially significant status.

The main components (indicators) of social success of students can be considered: adequate self-esteem, high level of claims, self-confidence, a high level of self-esteem; satisfaction and work attitude as self-worth, sense of selfimportance.

Social success insurance requires that the principle of success and success in terms of student life was laid in the basis of its educational system, where success is seen as a prerequisite and as a normal fulfilling life.

Table 1. "Social success of future primary school teachers" concept components

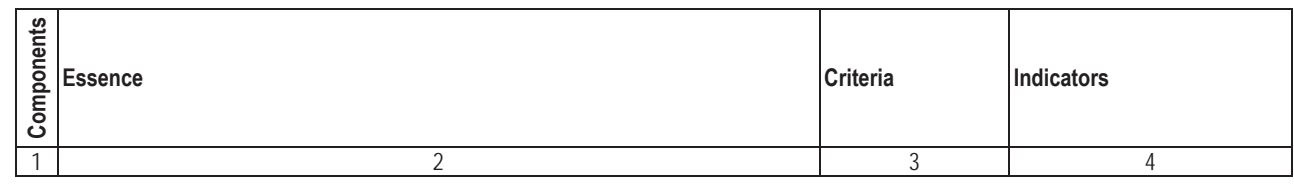




\begin{tabular}{|c|c|c|c|}
\hline 흘 & Assumes successful social adaptation, the formation of social attitudes & Self-realization & $\begin{array}{l}\text { - Dedication } \\
\text { - Creativity } \\
\text { - Self-expression } \\
\text { - Communication } \\
\text { - Social experience }\end{array}$ \\
\hline 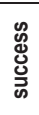 & $\begin{array}{l}\text { Reflects the high motivation of achievement; the formation of personal and social } \\
\text { qualities of students }\end{array}$ & $\begin{array}{l}\text { Personal } \\
\text { satisfaction }\end{array}$ & $\begin{array}{l}\text { - Independence } \\
\text { - Social optimism } \\
\text { - Confidence } \\
\text { - Organizational skills }\end{array}$ \\
\hline 总 & $\begin{array}{l}\text { Represents the totality of socially significant actions aimed at intensive, deliberate } \\
\text { interaction with the social environment, engaged in the process of internal activity }\end{array}$ & Social vocation & $\begin{array}{l}\text { - Self-esteem } \\
\text { - Credibility } \\
\text { - Social responsibility } \\
\text { - Initiative }\end{array}$ \\
\hline
\end{tabular}

Thus, the social success of future primary school teachers in the teaching process of the University is a holistic system, content and semantic unity components such as social position, personal success, social activity, developed in sociocultural activities, to ensure the successful fulfillment, personal satisfaction and social recognition.

\section{Methods}

The purpose of this pilot study was to determine the level of social success of future primary school teachers in pedagogical process of high school. We hypothesized that the development of social success of future primary school teachers depends on adequate self-esteem, high level of claims, self-confidence, high level of self-esteem; satisfaction and its activity, attitude as self-worth, sense of self-importance.

The study involved 1 - 2 year students in the number of 104, the specialty 5V010200 - "Pedagogy and methodology of primary education" Abai Kazakh National Pedagogical University and Almaty University (2014-2015), Almaty.

To study the level of social success of future primary school teachers we used personal achievements assessment test by E.F. Zeer and O.P. Shakhmatov; diagnostics method of personality motivation to success (T. Ehlers); modified test by N. M. Pejsakhov "Perceptions of social success".

\section{Results}

The analysis of psychological and pedagogical literature, the pilot study allowed us to distinguish three levels of development of social success of future primary school teachers. Let's characterize the levels.

The low level development of social success of future primary school teachers is characterized by a predominance of focus on the achievement of pragmatic goals. Social position is characterized by the copying behavior patterns, formulaic execution of tasks, willingness to use knowledge in various types of professional activity of the surface. The student is involved in the development and implementation of projects within the framework of the proposed activity, only in connection with the requests and demands of the teacher. The activity itself, being built on a pre-established scheme, which became the algorithm, is monotonous. The student does not feel personal satisfaction, often has inadequate selfesteem, does not possess the self-organization of activity, and does not seek to act independently. On this level an arbitrary activity occurs (due for the purpose and will of the subject) and situational activity (i.e., corresponding to the requirements of the situation sufficient to tackle the issues that arise in a given activity).

The average level development of social success of future primary school teachers is differ in more focusing, sustainable value attitude to the activity, awareness of its ways and means, the desire to take the initiative, going beyond the proposed limits of work, broadening their horizons, making trial of their strength in innovation projects. The student's performance shows elements of a search for new solutions in standard situations. The student is often included in various activities, shows initiative. The formation of communicative and organizational skills makes his work more productive. The student masters the basic methods of knowledge and analysis of their own activities, is able to get satisfaction from creative work, uses the basic techniques of self-organization, self-esteem has close to adequate. At this level the student carries out search activity, aimed at finding ways to overcome difficulties, to change the situation in the absence of a definite forecast of the outcome of the whole situation. However, this is highly irregular, the activity is characterized by a medium level of concentration, and the position of a student is performing an activity, rarely traced interest in the independent creative search. 
The high level development of social success of future primary school teachers. Characterized by the ability of the student to set a goal, the integrity of the system of social knowledge and the willingness to use them. Activity is recognized as personal and social responsibility and has a profoundly transformative feature. The student feels the author of his own life, has his own strategy, which he seeks to realize, therefore he is initiative, developing innovation, sets goals, achieves results. He is a subject of activity, regularly shows social activity, organizes and implements projects, promotions, programs, etc. He receives personal satisfaction from his own activities, has adequate self-esteem, stable social position.

\section{Discussion}

For translation of qualitative characteristics into quantitative equivalents, we have introduced the following quantitative indicators:

1 point - if there is a low level of formation of the indicator;

2 points - if the observed average level of formation of the indicator;

3 points - if there is a high level of development indicator.

The evaluation mechanism or another score of each indicator are presented in table 1.

Table 1. The mechanism of assessing the level of development of social success of future primary school teachers

\begin{tabular}{|l|c|c|c|}
\hline \multirow{2}{*}{ Indicators } & \multicolumn{3}{|c|}{ Levels and points for each level } \\
\cline { 2 - 4 } & Low (1 point) & Average (2 points) & High (3points \\
\hline Communication skills & 1 & 2 & 3 \\
\hline Dedication & 1 & 2 & 3 \\
\hline Creativity & 1 & 2 & 3 \\
\hline Expression & 1 & 2 & 3 \\
\hline Social experience & 1 & 2 & 3 \\
\hline Social optimism & 1 & 2 & 3 \\
\hline Organizational skills & 1 & 2 & 3 \\
\hline Confidence & 1 & 2 & 3 \\
\hline Independence & 1 & 2 & 3 \\
\hline Self-esteem & 1 & 2 & 3 \\
\hline Authority & 1 & 2 & 3 \\
\hline Social responsibility & 1 & 2 & 3 \\
\hline Initiative & 1 & 2 & 3 \\
\hline Activeness & 1 & 2 & 3 \\
\hline
\end{tabular}

It is easy to see that the total score in table 1 for all indicators varies from 0 to 32 . The choice of intervals for grouping data of students distribution totality by level of development of social success of future primary school teachers was carried out on the basis of the methodology by A. A. Kyveryalga (1995), according to which the average level is determined by the $25 \%$ deviation of the estimate from the average of the range of estimates of the score, then the score of the interval from R ( $\mathrm{min}$ ) $0.25 \mathrm{R}$ (Shah) suggests a low level. The high level shows scores exceeding $75 \%$ of the maximum possible. Based on this methodology, the development levels of social success of future primary school teachers was determined by the intervals presented in table 2 .

Table 2. The technique of determining the levels of development of social success of future primary school teachers

\begin{tabular}{|c|c|c|c|}
\hline Level & Low & Average & High \\
\hline Points & $0-10$ & $11-21$ & $22-32$ \\
\hline
\end{tabular}

We recorded the scores of each student in the summary table 3.

Table 3. A snippet summary data diagnosing the development level of social success of future primary school teachers

\begin{tabular}{|c|c|c|c|c|c|c|c|c|c|c|c|}
\hline \multirow{2}{*}{$№$} & \multirow{8}{*}{ Student name } & \multicolumn{7}{|c|}{ Indicator points } & \multirow{2}{*}{ Total } & \multirow{2}{*}{ Level } \\
\cline { 3 - 9 } & & 1 & 2 & 3 & 4 & 5 & 6 & $\ldots$. & 14 & & \\
\hline 1. & K.N.Makarova & 1 & 1 & 2 & 1 & 0 & 2 & & 1 & 16 & Avearge \\
\hline
\end{tabular}

Note: in the table the numbers are highlighted and described above indicators of criteria. 
The decision of the question on what level of criterion formation the student is, resolved on the basis of a comparison of received total score (table 3) with a scale measuring the level of formation criterion (table 2). This is the mechanism evaluation results of the pilot study.

\section{Summary}

Our study shows that the state of development of social success of future primary school teachers passes gradually. Each level leads to the following, included in its composition, which ensures the formation of social attitudes, personal success, social activity of students.

Our defined the levels and criteria of formation of the components of social success of future primary school teachers are relative to some extent, because, undoubtedly, there are other indicators and criteria. But we believe that these criteria, which we defined on the basis of theoretical analysis of literature and own research and practice, reflect the real development of social success of future primary school teachers.

In summary the results of diagnostics of the level of development of social success of future primary school teachers are presented in table 4.

Table 4. A summary of the status of development of social success of future primary school teachers in the preparatory phase of the experiment

\begin{tabular}{|c|c|c|c|c|c|c|}
\hline \multicolumn{2}{|c|}{ Low } & \multicolumn{2}{|c|}{ Average } & \multicolumn{2}{c|}{ High } & \multirow{2}{*}{ Total } \\
\cline { 1 - 5 } amount & $\%$ & amount & $\%$ & amount & $\%$ & \\
\hline 31 & 30 & 50 & 48 & 23 & 22 & 104 \\
\hline
\end{tabular}

Thus, the results of an experimental study show the lack of development of social success of future primary school teachers, which led to the necessity of organizing special conditions for the development of social success of future primary school teachers in pedagogical process of high school.

In this study, we examined the diagnostic criteria of the diagnostic toolkit of social success of future primary school teachers and the methodology for the study of social success of future primary school teachers in the process of professional training.

\section{References}

Abdulkhanova-Slavskaya, K. A. (1980). Activity and personality psychology.Psychology(p. 335). Moscow, Russia: Education

Asmolov, A. G. (2002). Psychology of personality: principles of General psychological analysis / Asmolov,A. G. Psychology of personality (p. 416). Moscow, Russia: Significance

Leont'ev, A. N. (1975) Activity, consciousness, personality(p. 77). Moscow, Russia:Academy

Petrovsky, A. V. (1996) Personality psychology: the paradigm of subjectivity / V. A. Petrovsky(p.512). Rostov-on-Don, Russia: Phoenix

Rubinstein, S. L. (1986)The principle of creative initiative // Questions of psychology. 4(pp. 34-37).

Tulchinsky, G. L. (1994) Russian spiritual experience and the problem of success / Ethics of success. Volume 3 (pp. 19-26). Tyumen, Russia:Moskva

Bakshtanovskii, V. I. (1996) Success Time: the Problems of ethics in the XXI century // Ethics of success. Volume 3 (p. 145-154) . Tyumen, Russia:Moskva

Belkin, A. S. (2004) Competence. Professionalism. Skills. Chelyabinsk, Russia: JSC "South Ural publishing house", -

Gazman O. S. (1995) From authoritarian education to pedagogy of freedom. New value of education(p 16-45). Volume 2. Moscow, Russia.

Mudrik, A.V. (2000) Social pedagogy: textbook for students of pedagogical universities. Slastenin,V. A. (Ed) Volume 2.(p.192) Moscow, Russia: Academy

Varlamova, E. Y. (2004) Organizational and pedagogical conditions providing social success students: abstract of dissertation p.24. Kostroma, Russia.

Istufeeva, J. N. (2008) Subjective resources achieve the success of personality: the case of professional pedagogical activity: abstract of dissertation (p. 22). Novosibirsk, Russia.

Klochkov, O. Y. (2003) Model of success as a factor in occupational choice (on the example of the students from the Moscow pedagogical universities): abstract of dissertation (p.24).Moscow, Russia.

Klyuchnikov, S. Y. (2003) Success Philosophy: epistemological analysis: abstract of dissertation (p.24). Moscow, Russia.

Kazimirskaya, L. N. (2002) Pedagogical conditions of social success of students in the modern school: abstract of dissertation p.25. Omsk, Russia

Krylov, N. B. (1995) Socio-cultural context of education. New value of education(pp. 67-103).Volume 2. Moscow, Russia. 
Gazman O. S. (1996) Pedagogy of freedom: the way of the humanistic civilization of the 21st century.New values of education: the content of humanistic education(pp. 10-38). Moscow, Russia.

Kovalev, B. C. (2002) NLP reprogramming own destiny (p.63).Moscow, Russia.

Basova, V. M.(2002) Need? - Don't need it?!: A differentiated approach to the concept of security. Theory, History, Technique of children's movement (TIM) (p. 14). Newsletter. Volume 6. Kostroma, Russia. 